\title{
報 文
}

\section{SBRとシリカの混合系における熱処理}

\author{
（昭和39年11月18日 受理）
}

\section{尾野敬三*1 鈴木 敏 弘 ${ }^{* 1}$ \\ 松下秀夫墧田泰三*2}

\begin{abstract}
要 旨 Silica 配合物がカーボンブラック配合物とほぼ等しい静的補強効果をもっていることは天然ゴ ムの場合と同様に SBR に扎いても同じであるが，動的性質はやはりかんばしくない。そこで第 1 報と同様 な実験空 SBR についで行ない，SBR-シリカ系コンパウンドの物性改善のためバンバリー操作条件を検討 した.

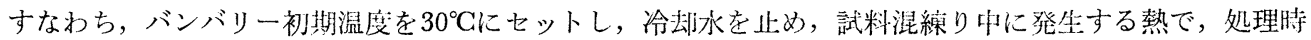
間を 0 分，10分，20分間と定めて実験を行なったところ，この熱処理によりシリカの欠点とされていた，動 的性質が改菩された。 そこでさらに詳しく調べるために天然ゴムーシリカ采の熱処理方法と同様に, 次の処 理条件から最適点をみつけようとした。
\end{abstract}

バンバリー初期温度； $30,60,90^{\circ} \mathrm{C}$

熱 処 理 時 間; $0,10,20$ 分

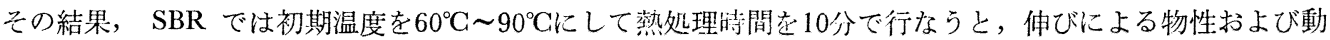
的性質を大幅に改善することができた.

\section{1. 緒言}

SBR-カーボンブラック采の 熱処理に関するものは, 古く主として Parkinson'1)などによって確立した研究が ある。それによれば熱処理をすることによって，引㖘強 さと引裂強さが多少覀くなっているが，引張応力が大き くなり,また反ぱつ弾性, 摩耗減量, 㧍よび電気的性窉 なども改良されている。そ㧈に対し SBR-シリカ系の熱 処理に関する研究もこ机生でに 2,3の報文が出されてお り，Gessler などによるとオープンロールおよびバンバ リーで熱処理実験を圾みている。その Gessler などの奏 験結果は Parkinson などの実験結果とほぼ同様な効果を シリカで見いだしているが，深く熱処理の操作条件を求 めていない。 また Parkinson と同様な方法で Ecker ${ }^{2)}$ どもSBR 1500 とシリカで熱処理実験を行なっている.

上述のように，これらの報文をもとにして，われわれ は SBR 1502 とニップシール VN 3 (シリカ) でバンバ リーミキサーを用いて，その熱処理操作条件の最適を見 いだそうとした。

†本報を〔ゴムとシリカの混合系における熱処理に関 する研究（第 2 報）]とする

*1 日本シリカ工業株式会社

*2 東洋ゴム工業株式会社中央研究所

\section{2. 実 験 方 法}

第 1 報と同様な方法でこの実験を進めたが，バンバリ 一の内部の初期温度は天然ゴムの熱処理方法より低くと り $30^{\circ} \mathrm{C}, 60^{\circ} \mathrm{C}, 90^{\circ} \mathrm{C}$ と選択した。処理時間は第 1 報と同 㥞な時間它設け，0分，10分，20分とした。このよらな采 件にあてはまるようにバンバリー内の温度をスチームで 保ち，エア㧍よび冷却水学締奶って表 1 の配合で志ず (1)マスターバッチの混練り後(2)の熱処理作業を所定の時 閒だけ行なう。このとき充てル剤意配合しているのでバ ッチの湴度は急に上昇する。熱处理はその摩擦熱で行な った，熱処理の終ったバッチを直ちにバンバリーから取 り出し，ロールで加硫剂を配合する。流加硫条件は $150^{\circ} \mathrm{C}$ で10分〜90分で加硫した.

表 $1 \mathrm{SBR}$-シリカ熱処理配合

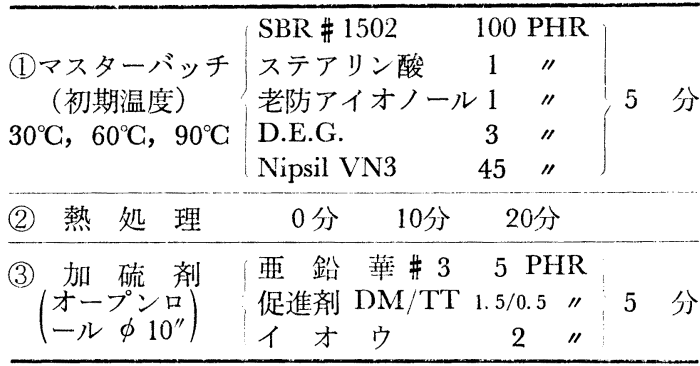




\section{3. 実 験 結 果}

図 1 に加硫時閒30分の場合の, 応力一ひずみ曲線を示

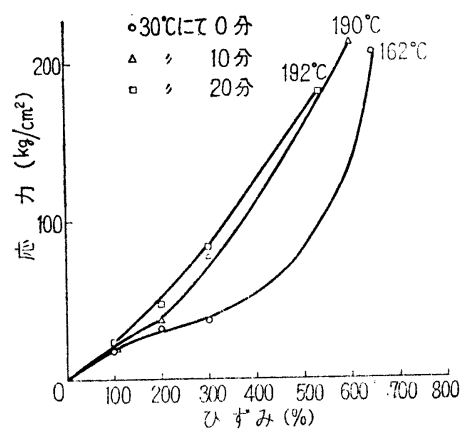

図 1 応力一ひずみ曲線

す。末端の温度はコンパウンドをバンバリーから取り出 したときの温度である。米熱処理のものは（30ㄷにて0 分） $100 \% \sim 300 \%$ みずで緩和の状態が見られる.10分 熱処理では引張強さ（曲線の末端の值）にわずかの增加 があるが，20分では明らかに，ポリマーの劣化と見られ る低下がある。熱処理時間の延長とともに, 引張态力の 上昇がある。このように, SBR 1502 でも引張応力の上 昇から動的性質の改良される方向に，一応熱処理によ。 て達成されるが，ポリマーの劣化を充分教虑しなければ ならない。

図 2 に加硫時間と $300 \%$ 引張态力の関係を示す.

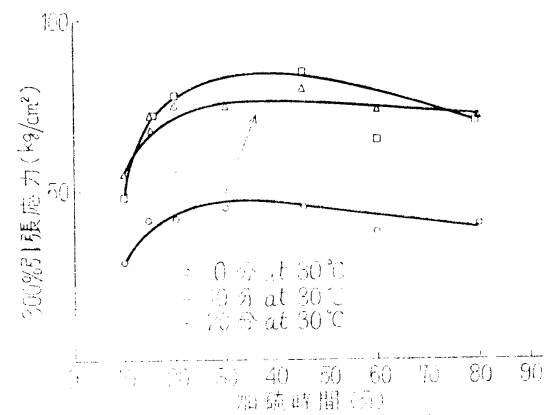

図 2 加硫時間と $300 \%$ 引張応力との関係

天然ゴムの時と同様に，熱処理によって一定のレベル アップがある。しかし天然ゴムと異なり引張応力の最適 值が熱処理によって早くなる傾向はない，したがって天 然ゴムの時の考察が，そのままあてはまらない。表 2 に スコーチタイムを示すが, 天然ゴムは早くなり SBR は遅 くなっている。この原因はおそらくポリマーゲルの生成

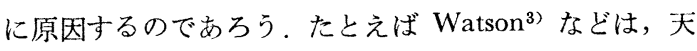
然ゴム, SBRの素練り時間とポリマーゲル生成量の関係
表 2 ムーニースコーチタイム $45 \mathrm{up}$ 比較表

熱処理時間（分） $0010 \quad 20$

ゴム種類

\begin{tabular}{lrrr}
\hline SBR \#1502* & $32^{\prime} 40^{\prime \prime}$ & $43^{\prime} 50^{\prime \prime}$ & $45^{\prime} 40^{\prime \prime}$ \\
天 然 ゴ ム** $^{\prime}$ & $9^{\prime} 04^{\prime \prime}$ & $7^{\prime} 22^{\prime \prime}$ & $7^{\prime} 08^{\prime \prime}$ \\
\hline
\end{tabular}

* 表 1 配合の值

** 第 1 報, 表 2 の值

から，SBRの方がはるふに早い時間に，ゲルの増大を確 認している。 また合成ゴム加工研究グループ4)などは SBR 1502 のポリマーゲルは $100 \sim 130^{\circ} \mathrm{C}$ 以上で急激に增 大しているが，物性が低下寸ると埌告している。このよ うなことから SBR を10分，20分と熱処理している内 に，ポリマーゲルが壇大し，または破壊されて加硫堂遮 らせる原因となっているのだろう。

次に最適熱処理条件を見つけるために実験方法でも述 ベたように，バンバリー内初期温度を $30^{\circ} \mathrm{C}, 60^{\circ} \mathrm{C}, 90^{\circ} \mathrm{C}$ とし，また熱処理時間を 0 分，10分，20分，の条理条件 で表 1 の配合に従って実験を行なった．最適加硫時間は 引張态力の最高值を選んで，図 3 から図 8 东でに諸物性 の值をグラフにして示した。

a. 引張強さ（罒3）初期温度が高いほど, 引張强

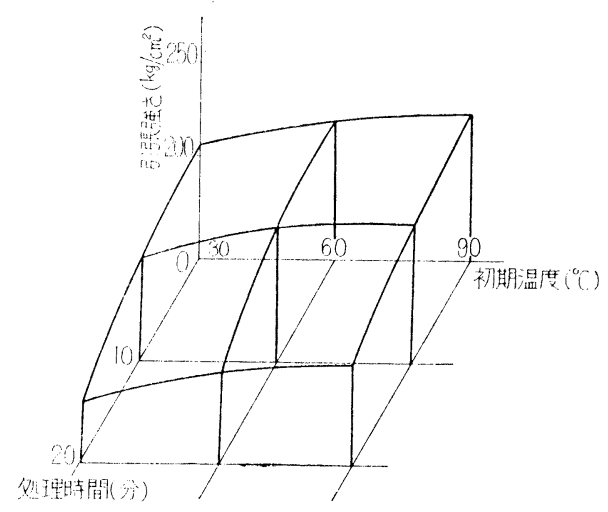

図 3 引! 張 強さ

さ多わずかづつ大きくなっている。专た処理洔間を延長 するほど，物性の低下が目だっている。しかしながら天 然ゴムの場合と比較すればそれほど低下していない。こ の理由は耐熟性の点において SBR の方が強いからであ ろう.

b. 300\%引張応力（図 4) 初期温度が商いほ上゙わず かに高く，処理時間による引張応力の上昇は大きい. 


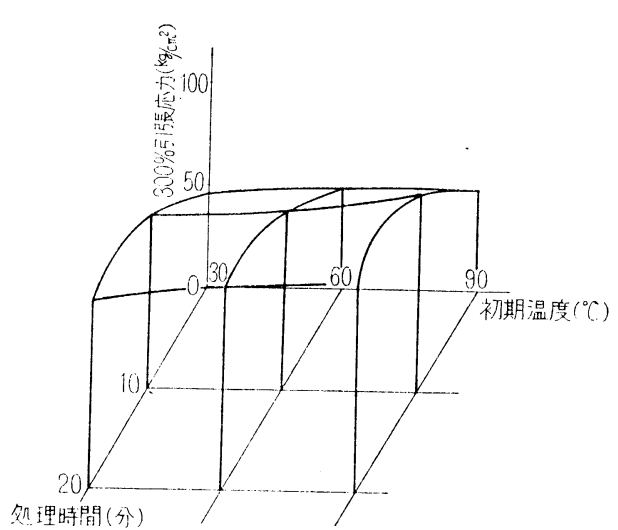

図 $4300 \%$ 引張灾打

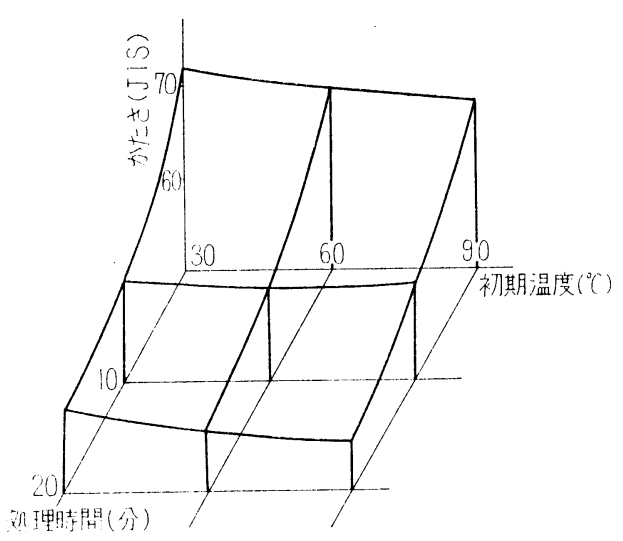

网5 かたさ

熱処理の進行に彷ってわずからつ低下している。これ も処理温度の影響より処理時間の影醄の方が大きい。す なわちバンバリーミキサーによる混練り効果が及ぼす影 響は大きい。また熱処理によって，シリカが原因となっ ている異常なかたさをなくす效果が見られる。

\section{c.反ぱつ弾性（図 6 ）}

初期温度, 処理時間を進めることによって, 弾性率は 大きくなるが， $30^{\circ} \mathrm{C} \times 20$ 分， $90^{\circ} \mathrm{C} \times 10$ 分，20分は逆に低 下している。また天然ゴムの時ほど大幅な改良はない。

\section{d. 発 熱 度 (図 7 )}

熱処理による物性の改善の効果法, 天然ゴムほど大き くない.

e.ひずみ(図 8 )

熱処理による物性の改善の効果は天然ゴムほど大きく

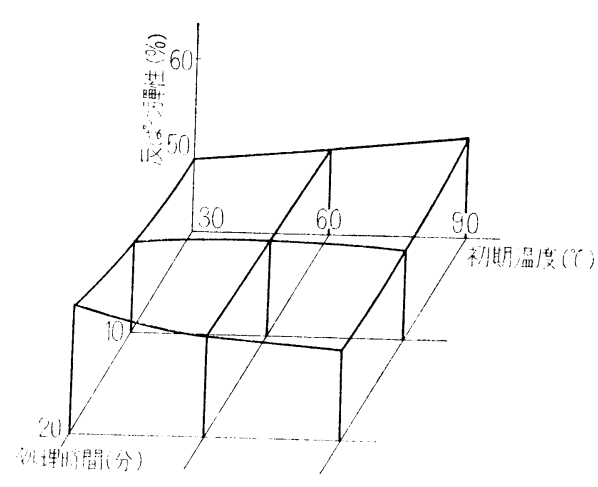

网6 反ぱつ弾性:

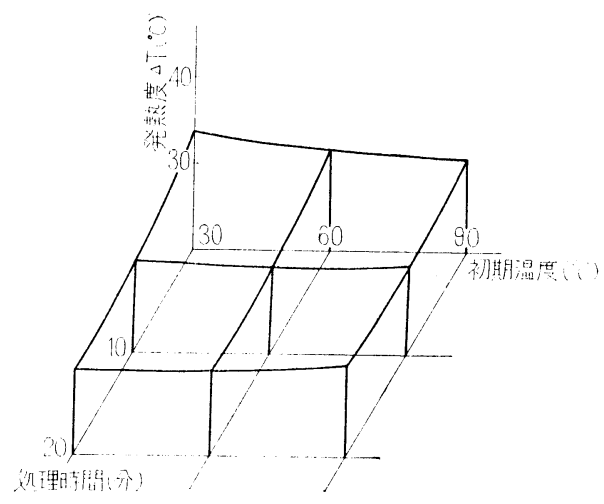

図 7 発 熱 度

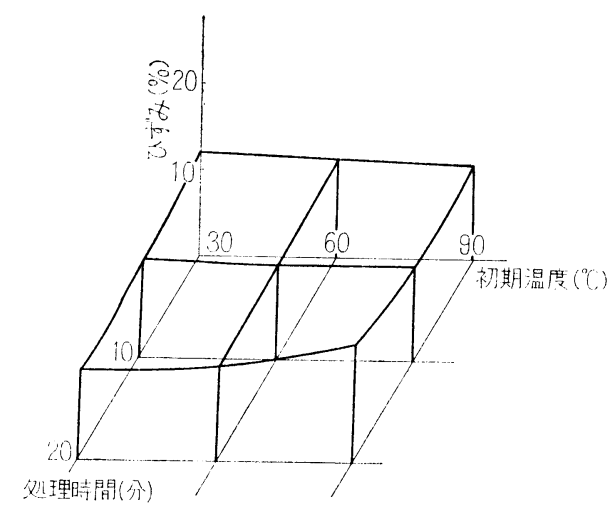

図8ひずみ 
ない.すなわち SBR-シリカ系熱処理は加硫遅れから発 熱，反ぱつ弾性，ひずみの改善に天然ゴムの時ほど大幅 な効果をもたらさなかった。この原因はさきに述べたよ らに，熱処理中生成されるポリマーゲル量のためだと思 われる。われわれはポリマーゲル生成量のチェックは行 なっていないが，合成ゴム加工研究グループ4などの実 験データ，あるいは Watson ${ }^{3)}$ などが天然ゴム, SBRの 素練り時間とゲル生成量との関係で SBR の方が，はる かに早期にゲルの生成を見いだしている事実から，この ような考察を加えても妥当であろうと思われる。したが って第 1 報での物性に与える影響において，ポリマーー ポリマー架橋のできる前に，できるだけ効果的にポリマ ーーシリカ凝着 (bound rubber) をさせるのだと述べた が, SBR では熱処理中, 多大に生成されるポリマーーポ リマーゲルがポリマーーシリカ凝着を妨げているのでは ないかと考えられる。そのために動的性質の改良が天然 ゴムほど大幅でなかったのであろうと想像される。

\section{4. 考察}

熱処理によって動的性質を改善させる要素は, 不均一 分散の改善であるが，その改良によってルーズなポリマ 一とシリカおよびシリカとシリカ凝集を除き, 強国なポ リマーシリカ凝着を生成させることにある。われわれは $100 \mathrm{PHR}$ 以上を配合した加硫物などで 伸長性を測定す

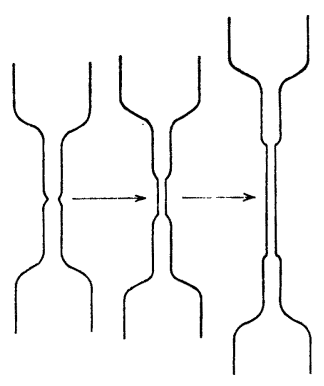

図 9 塑 性 変 形

る場合，図 9 のよらな部分的にくびれが生じ，それが成 厓していく現象をみる、試料片の外力をはずした場合， 変形がほとんどそのまま残り大きなひずみを与える。 こ の原因は高配合のためおこるシリカの不均一分散にもと ずくもので，好ましくないシリカの凝集，ルーズなポリ マーとシリカの凝着が伸長により簡単にはずれ, 再び変
形を回復させた場合, シリカ粒子はポリマーの網目に妨 げられて不凝着の状態のままひずみを残すのである。高 活性シリカは大きな比表面積をもち, ポリマー中で内部 摩擦抵抗索増大させるので大きな塑性変形が予測され る。熱処理による不均一分散の改良はここに意義があ 万.

熱処理による動的性質の改良のもう一つは，強固なポ リマーとシリカの凝着の生成である。

念水シリカはカーボンブラックと異なり吸湿性が大き く(汗衝水分 $7 \sim 8 \%$ ) Gessler などが，主として用い たcyclic 法 (milling/heat-treatment on open steam の繰 没し)ではあまり効果がなく， milling と同時に熟処理 をする dynamic な方法がよいとされている。これはシ リカ表面につ权に付着している水分で, 削者の方法では 充分抜けなく熱処理効果を充分に発揮することができな いからで，水があるとポリマーとシリカとの凝着ほど強 くならないからであらう。 R. Ecker6) がポリマーーシリ 力系熱処理に対する考察として 180〜200にコンパウン ドの温度が到達すると, シリカ表面の付着水分がほとん どゼロになり強固なポリマーーシリカ結合を作るのだと いっている。そこで熱処理中水分がゼロになるとなぜ弶 固にポリマーーシリカが凝着するか考えてみる. Gessler などのブチルーカーボンブラック系で試みた実験によれ ば，その原因はカーボンブラック表面の酸素であること を兒いだした。つ来りチャンネルカーボン，ファーネス カーボン配合物を熱処理した場合, 後者はほとんど熱処 理効果がなかったからである。

表 3 カーボンブラック酸素分 $(\%)$

\begin{tabular}{ll} 
HAF (ファーネス) & 0.79 \\
ISAF (ファーネス) & 1.17 \\
EPC (チャンネル) & 3.49 \\
\hline
\end{tabular}

表 3 で代表的なカーボンブラックの酸美分を示すが， ファーネス系は $1 \%$ 前後しか酸素がない. しかしファー ホスカーボンブラックの表面を酸化させた場合, 熱処理 効果を頮著に永わした。 またブチルーシリカ系でシリカ 袁面に多大に散在するシラノール基を減じた場合，熱処 理の效果を減じていることを見いだした。このように力 一ボンではカルボニル基, ケトン基, シリカではシラ, ール基として存在する酸素が熱処理に重要な働きをして いることがわかる．以上充てん阂の立場から熱処理によ る物性に及ぼす考えを述べたが, 次にポリマー自身高温 にさらされた場合どうなるかを見る。一般に高温におけ 


\title{
第38巻 第 9 号 (1965) 尾野敬三・鈴木敏弘・松下秀夫・橋田泰三
}

る混練りでは，酸素によるポリマー切断とそれにより生 成したラジカルの再結合が競争的に行なわれる。したが って，ポリマーの種類により二重結合が多いもの，極性 の強い側鎖を持つポリマーとかによって，ポリマーの切 断の度合いとか，再結合が非常に違ってくる。これらの 現象で最も熱処理に恐影響があると思われるのはポリマ 一ゲルの発生しやすいものである．われわれの天然ゴ ム, SBR 1502 の熱処理で後者のポリマーゲルの発生か ら各物性の改良が，天然ゴムほどなされなかった事実 や，また合成ゴム加工研究グループむなどの実験で SBR ポリマーゲル生成とともに大幅に物性の低下を示すこ

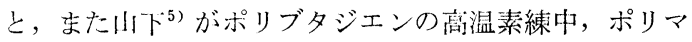
一ゲルが著るしく增して物性圭低下させることなどから ボリマーゲル発生の少ないポリマーの選定およびゲルを 発生しにくい条件のくふう（蓜品の添加）が必要であろ j.

\section{5. 結 論}

バンバリーミキサーで SBR-シリカ系コンパウンドを 熱処理し，動的性質を改良しようと検討した。

その結果次のようなここがわかった。
バンバリーミキサーの内部初期温度を $60^{\circ} \mathrm{C} か ら 90^{\circ} \mathrm{C} に$ 保ち10分間程度熱処理を行ならと引張強さ, 引張态力は 増大し，かたさが減少する。その他反ぱつ弾性, ひずみ の改良はわずかであったが，発熱量は少なくなった。

この実験の結果から天然ゴムと同様に SBR にシリカ を配合する場合, 混練操作条件をうまく設定することに より, 動的性質を要求するゴム製品がえられるものと思 われる。

（日本ゴム協会第31回通常総会で講演）

\section{6. 参 考 文 献}

1) Parkinson, D., and Blanchard, A. F.: Trans. Inst. Rubber Ind., 23, 259 (1948).

2) Ecker, R., Rosenthal, O. and Clamroth, R.: Kautschuk und Gummi, 13, 80 (1960).

3) Watson, W. F., et al.: Rubber Chem. Technol., 33, 80 (1960).

4) 合成ゴム加工研究グループ：日本ゴム協会誌, 第31回講演要旨, No. 22, 23 (1964).

5) 山下: ゴム協, 36, 883 (1963).

6) Ecker, R.: Gummi u. Asbest: No. 1, 20 (1959)

\section{STUDIES ON THE HEAT-TREATMENT IN THE SYSTEM OF RUBBER-SILICA MIXTURE}

\author{
II. HEAT-TREATMENT IN THE SYSTEM OF SBR-SILICA MIXTURE \\ K. Ono, T. Suzuki, K. Ishida, (Nippon Silica Ind. Co., Ltd.) \\ H. Matsushita, T. Hashida, (Toyo Rubber Ind. Co., Ltd.)
}

In this paper, the results are described which were obtained when: Natural rubber studied in previous paper was replaced by SBR, the initial temperature of Banbury mixer was set at $30^{\circ} \mathrm{C}$, supplying of cooling heat water was then stopped and the content was milled for 0,10 and 20 minutes and heated by the produced at the stage of milling.

As the result, disadvantages of silica were climinated through heat-treatment; then, in order to give full justice to the effect as in the case of natural rubber, an attempt was made to find out the optimum condition from those illustrated below:

Initial temperature of Banbury mixer: 30,60 and $90^{\circ} \mathrm{C}$,

Duration of heat-treatment: 0,10 and 20 minutes.

As the result, a compound was obtained with physical properties due to elongation and dynamic properties which were nearly satisfactory when the initial temperature was from $60^{\circ} \mathrm{C}$ to $90^{\circ} \mathrm{C}$ and time of heat-treatment was 10 minutes. 